\title{
The archaeology of food surplus
}

Amy Bogaard

\begin{abstract}
Tracing flows of past food surplus challenges archaeologists to integrate a wide range of evidential strands for food acquisition, production and consumption, and to resist false dichotomies between 'economic' and 'political' accounts. Current approaches to the topic - variously illustrated by the papers brought together in this special issue - not only question traditional approaches to food surplus as a simple causal vector in social change (e.g. towards 'complexity'); they also make the case that understanding how societies addressed common problems of shortage and abundance, climatic uncertainty and power relations in the past should inform discussion of future food security.
\end{abstract}

Keywords

Food surplus, shortage, abundance, food security, climatic uncertainty

In 1999 a team led by Jürgen Seeher of the German Archaeological Institute in Istanbul made a remarkable discovery. A massive underground storage facility, tucked behind a defensive wall at the Hittite capital, Hattusha, north-central Turkey, was found to contain hundreds of tons of intact carbonized cereal grain (Seeher 2006). At capacity, the building would have stored enough grain to feed at least 20,000 people for a year (Seeher 2006: 81). Underground chambers and pits have also been detected at other Hittite sites, as well as in the Aegean Bronze Age world (e.g. Fairbairn and Omura 2005; Privatera 2014). But the example of Hattusha is unique in preserving intact what the Hittite state of the early $16^{\text {th }}$ century BC could actually mobilise. The grain assemblage itself, with its extremely good preservation and plentiful weed flora (Neef 2001; Dörfler et al. 2011), is a goldmine of information on the agro- and wider social ecology of Hittite farming. Analysis of the granary's contents - a collaboration between the School of Archaeology at Oxford and the German Archaeological Institute in Berlin - is currently unpacking this agroecological treasure (Diffey et al. in press).

Part of the fascination of the Hattusha granary is that the extreme efforts of the state to cache supplies against future emergencies failed spectacularly: by collecting together many tons of cereals, the central authorities made that production vulnerable to the destruction event that ultimately occurred. If the crops mobilized by the Hittite state had instead been managed by the dispersed farms and households that produced them, catastrophic losses would have been less likely. But the granary was also important politically: planned together with the defensive postern wall that encircled the Lower City area of the new capital, it formed part of an ambitious building programme intended to announce the new status of Hattusha, and the power of its rulers (Seeher 2006: 49, 74).

The Hattusha granary is an unusually clear instance of how a particular social group defined and handled food surplus, and interpreting it automatically requires us to consider both ecological and political dimensions. Like food in general, the topic of surplus food is powerful because it confronts us with contrasting, non-mutually exclusive ways of framing its role in a society, from the biological to the ideological. Moreover, the concept of surplus food has played a pivotal role in conceptualising 
how societies operate and change, from Locke and Smith to Marx, Sahlins and beyond. It is a key component of accounts of linear social 'evolution' (e.g. Childe 1929, 1950, 1957) that have been influential across the social sciences (e.g. Boserup 1965, Lenski 1966), and more recently in notions of social 'complexity'. Food surplus is thus a promising focus of scrutiny for critiquing and refining approaches to longterm social history.

Unfolding events, ranging from the great recession of the late 2000s, to handling of the refugee crisis in Europe, to the long-term consequences of global warming for land use and production, have raised the profile of surplus in other ways. The Food and Agriculture Organisation of the United Nations estimates, for example, that around $30 \%$ of food is wasted, the highest levels occurring in industrialised countries (FAO 2011). This ‘hidden’ surplus fails to make a contribution to global food demand; it also entails avoidable greenhouse gas emissions, exacerbating future climate change and food shortages. Alongside campaigns to reduce food waste (FAO 2015), current framing of the problem of ensuring food security targets bottom-up improvement of agricultural sustainability among smallholders (FAO 2016). Many of the sustainable improvements and practices now recommended to address both food shortage and climate change focus on a shift away from high-input 'elite' crop strains and a return to lower yielding varieties attuned to local soils and conditions, combined with diversified cropping and land use practices strongly reminiscent of smallholder tactics that can be traced into the deep past (e.g. Halstead 2014; Nitsch et al. this volume). There are important ways in which archaeology can and must contribute to discussion of future food security, including management of surpluses, under changing climatic conditions (cf. Sykes this volume).

Recent edited volumes devoted to excess and greed (Oka and Kuijt eds 2014), surplus resources, goods and/or labour (Morehart and De Lucia eds 2015), storage (Balbo ed. 2015) and abundance (Smith ed. in press) variously reflect renewed interest in surplus and its linkages with topics such as inequality, health and resilience. Nevertheless, a dichotomy between 'eco-rational' or 'political' understandings often continues to obscure what surplus is and how it functioned in particular societies and sequences (Earle 2015; Morehart and De Lucia 2015). Similarly, past discussion of surplus has been limited by insistence on a substantivist or formalist approach to economy, as though the heuristic value of either perspective were exclusive (e.g. Polanyi 1957; Harris 1959). In this context Pearson's (1957) insistence on the relative nature of surplus has not been entirely helpful: it is only by contrasting absolute surplus (over and above estimated biological requirements) with that portion regarded as surplus in any specific context that we can apprehend the cultural inflection on the latter (Halstead 1989: 70). Indeed, while the relative nature of surplus is now widely acknowledged, archaeologists frequently appeal to estimates of what would be required for survival to make a case for the scale of potential surpluses in play (e.g. Morehart 2014; Petek and Lane this volume).

How and why are surpluses consumed in particular ways, redistributed or neglected? What can we learn from the approaches different societies, past and present, have developed to the unequal distribution of resources? Food surplus is not only an urgent global concern, but also a key index of how different groups and societies have addressed common problems of shortage and abundance, climatic uncertainty and power relations in the past. The introductory argument developed here is that food 
surplus provides an opportunity to assess and integrate the biological and social dimensions of production and consumption. While this is hardly an original claim, it is both a challenge archaeologists have rarely tackled, and one that is increasingly within their grasp. Building an integrated understanding of what has constituted food surpluses in different societies and how these flows operated requires archaeologists to take full advantage of a wide range of relevant perspectives and evidential strands, including the status and practicalities of different foods (e.g. van der Veen 2003; Halstead 2007; Sykes this volume), consumption patterns relating to food processing, serving, dining and distribution (e.g. Wright 2000; Isaakidou 2007; Dunne et al. 2012; Gallimore this volume), storage practices including accessibility and display (e.g. Balbo ed. 2015; Bale, Urem-Kotsou this volume), study of human diet and nourishment ranging from stable isotope approaches to representations of the human body (Pearson and Meskell 2014; Costin 2015; Nitsch et al. this volume); reconstruction of actual (as opposed to potential) land use systems (e.g. Styring et al. 2016, in press; Nitsch et al. this volume); critical appraisal of textual and oral accounts (e.g. Killen 1998; Halstead 2014; Thurston 2015; Forbes this volume; Petek and Lane this volume); and comparison of an expanding range of well documented societies widely separated in space and/or time (Hastorf and Foxhall this volume). Collectively, these perspectives - variously represented by the papers brought together in this special issue - illustrate the diverse ways in which food surpluses were defined, produced and deployed, and directly challenge the traditional view that surplus constituted a simple causal vector in social change. It is startling to observe, for example, that a very long-term tradition of domestic production, including surplus handling, can be traced through later Greek prehistory (Urem-Kotsou this volume; Nitsch et al. this volume) to classical Athens (Foxhall and Hastorf this volume), recent times in rural Greece (Forbes this volume) and even urban refugee homes (Hirschon 1998). The characteristic persistence of the Greek household as a fundamental economic entity - the original meaning of oikonomia (Polanyi 1957) despite the intermittent rise and collapse of radical and institutionalized social inequality suggests very long-term cultural patterning in the manipulation of food surplus.

The ground gained by improved granularity and complementarity of archaeological inference from material evidence (e.g. Chapman and Wylie eds 2015), alongside interdisciplinary synergies, should bring archaeologists closer to a fuller understanding of the perspectives offered by handling and deployment of food surpluses. But this potential depends on resisting dichotomized views of surplus as a phenomenon to be understood as economic or political, biological or social. Allan's original identification of 'normal surplus' among subsistence maize producers in early-mid $20^{\text {th }}$ century Rhodesia (Allan 1965: 38-48) is a case in point: his account makes clear that production of maize surpluses in average years was simultaneously 'about' ensuring adequate supplies in bad years and being able to host beer working parties, prestigious individuals etc. While it is possible to delineate various 'funds' farmers may seek to provide - a replacement fund (seed corn etc.), a ceremonial fund, a rent fund (Wolf 1966: 4-17) - in practice there will be a dynamic relation amongst these flows depending on shifting conditions from one year to the next.

The recognition of 'normal surplus' has proved fundamental for understanding production and consumption strategies among small-scale producers in the recent and deep past, and its potential for ramping up or dampening lasting social inequality 
(Halstead 1989). Forbes' contribution here illustrates how normal surpluses of grain production in the peninsula of Methana, southern Greece depended on access to sufficient land; unequal land ownership undermined the security of poor households and fuelled emigration. In other recent work on normal surplus, Winterhalder et al. (2015) used a simulation approach to show how political obligations to give away surplus threaten its stabilizing function. Normal surplus is therefore vulnerable to compromise where prevailing social inequality limits access to land, or where social obligations become excessive. Particularly in the wake of ecological crisis, normal surplus production can also foster communal cohesion and communitas (Petek and Lane, this volume).

Work on normal surplus forms part of a broader shift in the literature from the presumption of top-down intervention in productive practice and surplus-related motivation to bottom-up innovation and interests (e.g. Erickson 2006). The consequent challenge is to trace the interplay between the strategies of different social groups in producing and consuming food surpluses. Consideration of food surplus production and handling in social groups lacking overt inequality can reveal differences in strategy between communities and households, as well as in the consumption of foods with contrasting storage potential (Urem-Kotsou this volume; Nitsch et al. this volume). Such studies, in turn, can inform investigation of cases where lasting social inequality is readily apparent. Bale's study of Bronze Age Korea shows how material evidence of storage and its spatial configuration suggests mobilization of normal surpluses at central sites rather than control of production (cf. van der Veen and Jones (2006), for the example of English Iron Age hillforts). Bolender's recent study of tenant farming in Viking Iceland reveals how rent payment led to intensified management of marginal land as new 'home-fields' were established on tenant farms (Bolender 2015). Elite influence on farming practice took a different form in the Bronze Age Aegean, where analysis of Linear B records has revealed elite intervention in the form of loans of plough oxen to local communities (Killen 1993), but in association with production on village-owned land that was likely already under some form of extensive management (Killen 1998; Halstead 2001). Both Icelandic and Aegean cases, therefore, reveal a tendency of elites to co-opt existing strategies, rather than inventing and imposing new regimes. Moreover, such co-opting strategies have been shown to prompt various forms of non-elite innovation and resistence, often involving relatively mobile regimes (pastoralism, swiddening etc), from south-east Asia to Scandinavia (Scott 2009; Thurston 2015). Political conditions always shape food surplus production and consumption, and elites are not all similarly extractive (e.g. Blanton et al. 1996). Hastorf and Foxhall (this volume) present a stark contrast between the Inka state and classical Athens that illustrates very different attitudes to surplus mobilization by central authorities.

Whatever the political context, understanding what is being mobilized as surplus and the ecology of its acquisition requires investigation beyond storage practices and settlement patterns to production systems (cf. Earle 2015). Were elites skimming small-scale surpluses produced by subsistence-oriented households, for example, or sponsoring large-scale agrosystems oriented to significant surplus production? Investigating such scenarios has the potential to reveal not only flows of surplus but also the nature of power relations maintained and even fuelled by surplus mobilization itself. In the early urban landscapes of rain-fed northern Mesopotamia, for example, recent agroecological analysis of archaeobotanical crop and arable weed 
assemblages has revealed a tendency for demographic aggregation to promote more extensive, low-input forms of land management (Bogaard et al. in press; Styring et al. submitted). These expanding agrosystems not only had much greater surplus potential; they also fuelled pressure on land, promoting greater inequality of landbased wealth.

The papers brought together here and in other recent edited volumes (e.g. Balbo ed 2015; Morehart and De Lucia eds 2015) point the way forward for reassessing the roles of food surplus in long-term social histories. Archaeologists are uniquely placed to chart how strategies of food acquisition and distribution have succeeded or failed in sustaining societies under varying political regimes and in changing climatic conditions. An emerging challenge is to reorient these insights to inform present-day responses to problems of future food security and management of surpluses.

\section{Acknowledgements}

I would like to thank the authors of the papers brought together here for their fresh explorations of what constitutes food surplus, past and present. I thank Paul Halstead for thought-provoking discussions of this topic, and two reviewers for helpful suggestions to sharpen this brief introductory paper.

\section{References}

Allan, W. 1965. The African Husbandman. Edinburgh: Oliver and Boyd. Balbo, A. L. ed. 2015. 'Special Issue: Storage.' Environmental Archaeology 20.

Blanton, R. E., G. M. Feinman, S. A. Kowalewski and P. N. Peregrine. 1996. 'A dualprocessual theory for the evolution of Mesoamerican civilization.' Current Anthropology 37: 1-14.

Bolender, D. J. 2015. 'From surplus land to surplus production in the Viking Age settlement of Iceland.' In Surplus: The Politics of Production and the Strategies of Everyday Life, edited by C. Morehart and K. De Lucia, 153-174. Boulder: University Press of Colorado.

Bogaard, A., A. Styring, M. Ater, Y. Hmimsa, L. Green, E. Stroud, J. Whitlam, C. Diffey, E. Nitsch, M. Charles, G. Jones and J. Hodgson in press. 'From traditional farming in Morocco to early urban agroecology in northern Mesopotamia: combining present-day arable weed surveys and crop isotope analysis to reconstruct past agrosystems in (semi-)arid regions.' Environmental Archaeology.

Boserup, E. 1965. The Conditions of Agricultural Growth. New York: Aldine Publishing Company.

Chapman, R. and A. Wylie eds. 2015. Material Culture as Evidence. London: Routledge.

Childe, V. G. 1929. The Danube in Prehistory. Clarendon Press, Oxford.

Childe, V. G. 1950. The urban revolution. Town Planning Review 21:3-17.

Childe, V. G. 1957. The Dawn of European Civilization. Routledge, London.

Costin, C. 2015. 'The cost of conquest: assessing the impact of Inka tribute demands on the Wanka of Highland Peru.' In Surplus: The Politics of Production and the Strategies of Everyday Life, edited by C. Morehart and K. De Lucia, 45-72. Boulder: University Press of Colorado.

Diffey, C., Neef, R. and Bogaard, A. in press. The archaeobotany of large-scale hermetic cereal storage at the Hittite capital of Hattusha. In Innovation versus 
Beharrung. Internationaler Workshop zu Ehren von Jürgen Seeher, edited by A. Schachner. Byzas 23. Istanbul: Ege Yayinlari.

Dörfler, W., Harking, C., Neef, R., Pasternak, R. \& von den Driesch, A. 2011. 'Environment and Economy in Hittite Anatolia.' In Insights into Hittite History and Archaeology, edited by H. Genz and D. P. Mielke, 99-124. Leuven: Peeters.

Dunne, J., R. P. Evershed, M. Salque, L. Cramp, S. Bruni, K. Ryan, S. Biagetti, and S. di Lernia. 2012. 'First dairying in green Saharan Africa in fifth millennium BC.’ Nature 486: 390-394.

Earle, T. 2015. 'Conclusions: surplus and the political economy in prehistory.' In Surplus: The Politics of Production and the Strategies of Everyday Life, edited by C. Morehart and K. De Lucia, 307-326. Boulder: University Press of Colorado.

Erickson, C. L. 2006. 'Intensification, political economy and the farming community. In defense of a bottom-up perspective of the past.' In Agricultural Strategies, edited by J. Marcus and C. Stanish, 334-363. University of California, Los Angeles: Cotsen Institute of Archaeology.

Fairbairn, A. and S. Omura. 2005. 'Archaeological identification and significance of ÉSAG (agricultural storage pits) at Kaman-Kalahöyük, central Anatolia.’ Anatolian Studies 55: 15-23.

FAO 2011. Global food losses and food waste - Extent, causes and prevention. Rome. FAO 2015. Global initiative on food loss and waste reduction. Rome.

FAO 2016. The state of food and agriculture - climate change, agriculture and food security. Rome.

Halstead, P. 1989. 'The economy has a normal surplus: economic stability and social change among early farming communities of Thessaly, Greece.' In Bad Year Economics: Cultural Responses to Risk and Uncertainty, edited by P. Halstead and J. O'Shea, 6880. Cambridge: Cambridge University Press.

Halstead, P. 2001. 'Mycenaean wheat, flax and sheep: palatial intervention in farming and its implications for rural society.' In Economy and politics in the Mycenaean palace states: Proceedings of a conference held on 1-3 July 1999 in the Faculty of Classics, Cambridge, edited by S. Voutsaki and J. Killen, 3850. Cambridge: Cambridge Philosophical Society.

Halstead, P. 2007. 'Carcasses and commensality: investigating the social context of meat consumption in Neolithic and Early Bronze Age Greece.' In Cooking Up the Past: Food and culinary practices in the Neolithic and Bronze Age Aegean, edited by C. Mee and J. Renard, 25-48. Oxford: Oxbow.

Halstead, P. 2014. Two Oxen Ahead: Pre-Mechanised Farming in the Mediterranean. Oxford: Wiley-Blackwell.

Harris, M. 1959. 'The economy has no surplus?’ American Anthropologist 6: 185-199.

Hirschon, R. 1998. Heirs of the Greek Catastrophe: The social life of Asia Minor refugees in Piraeus. Oxford: Berghahn.

Isaakidou, V. 2007. 'Cooking in the Labyrinth: exploring cuisine at Bronze Age Knossos.' In Cooking up the Past: Food and Culinary Practices in the Neolithic and Bronze Age Aegean, edited by C. Mee and J. Renard, 5-24. Oxford: Oxbow.

Killen, J. 1993. 'The oxen's names on the Knossos Ch tablets.' Minos 27-28: 101-7.

Killen, J. 1998. 'The rôle of the state in wheat and olive production in Mycenaean Crete.’ Aevum 72:19-23.

Lenski, G. E. 1966. Power and Privilege: A Theory of Social Stratification. New York: McGraw-Hill. 
Morehart, C. 2014. 'The potentiality and the consequences of surplus: agricultural production and institutional transformation in the northern basin of Mexico.' Economic Anthropology 1: 154-166.

Morehart, C. and De Lucia, K. (eds) 2015. Surplus: The Politics of Production and the Strategies of Everyday Life. Boulder: University Press of Colorado.

Morehart, C. and De Lucia, K. 2015. 'Surplus: The politics of production and the strategies of everyday life - an introduction.’ In Surplus: The Politics of Production and the Strategies of Everyday Life, edited by C. Morehart and K. De Lucia, 3-43. Boulder: University Press of Colorado.

Neef, R. 2001. 'Getreide im Silokomplex an der Poternenmauer (Boğazköy) - erste Aussagen zur Landwirstschaft.’ In J. Seeher, Die Ausgrabungen in BoğazköyHattuša 2000. Archäolgischer Anzeiger 3: 335-341.

Oka, R., and I. Kuijt. Eds. 2014. Social economies of greed and excess. Economic Anthropology 1(1).

Pearson, H. 1957. 'The economy has no surplus.' In Trade and Market in the Early Empires: Economies in History and Theory, edited by K. Polanyi, C. M. Arensberg and H. W. Pearson, 320-341. New York: Free Press.

Pearson, J. and Meskell, L. 2014. Biographical bodies: flesh and food at Çatalhöyük. In Early Farmers: the view from archaeology and science, edited by A. Whittle and P. Bickle, 233-250. London: British Academy.

Polanyi, K. 1957. 'The economy as instituted process.' In Trade and Market in the Early Empires: Economies in History and Theory, edited by K. Polanyi, C. M. Arensberg and H. W. Pearson, 243-270. New York: Free Press.

Privitera, S. 2014. 'Long-term grain storage and political economy in Bronze Age Crete: contextualizing Ayia Triada’s silo complexes.' American Journal of Archaeology 118: 429-449.

Scott, J.C. 2009. The Art of Not Being Governed: An Anarchist History of Upland South-East Asia. Yale Agrarian Studies. New Haven: Yale University Press.

Seeher, J. 2006. Ergebnisse der Grabungen an den Ostteichen und am mittleren Büyükkale-Nordwesthang in den Jahren 1996-2000, Boğazköy-Berichete 8. Mainz am Rhein: Philipp von Zabern.

Smith, M. L. ed. in press. Abundance: The Archaeology of Plenitude, edited by M. L. Smith. Boulder: University Press of Colorado.

Styring, A., U. Maier, E. Stephan, H. Schlichtherle and A. Bogaard. 2016. 'Cultivation of choice: new insights into farming practices at Neolithic lakeshore sites.' Antiquity 90: 95-110.

Styring, A., M. Rösch, E. Stephan, H.-P. Stika, E. Fischer, M. Sillmann and A. Bogaard. in press. 'Centralisation and long-term change in farming regimes: comparing agricultural practice in Neolithic and Iron Age south-west Germany.' Proceedings of the Prehistoric Society.

Styring, A. K., Charles, M., Fantone, F., Hald, M.M., McMahon, A., Meadow, R.H., Nicholls, G., Patel, A.K., Pitre, M.C., Smith, A., Sołtysiak, A., Stein, G., Weber, J.A., Weiss, H. and Bogaard, A. submitted. 'New isotope evidence for agricultural extensification reveals how the world's first cities were fed.' Nature Plants.

Thurston, T. 2015. 'Surplus from Below: Self-Organization of Production in Early Sweden.' In Surplus: The Politics of Production and the Strategies of Everyday Life, edited by C. Morehart and K. De Lucia, 121-152. University Press of Colorado.

Veen, M. van der 2003. 'When is food a luxury?’ World Archaeology 34: 405-427. 
Veen, M. van der, and G. Jones. 2006. 'A re-analysis of agricultural production and consumption: implications for understanding the British Iron Age.' Vegetation History and Archaeobotany 15: 217-228.

Winterhalder, B., C. Puleston and C. Ross. 2015. 'Production risk, inter-annual food storage by households and population-level consequences in seasonal prehistoric agrarian societies.' Environmental Archaeeology 20: 337-348.

Wolf, E. R. 1966. Peasants. Englewood Cliffs, New Jersey: Prentice-Hall.

Wright, K. 2000. 'The social origins of cooking and dining in early villages of western Asia.' Proceedings of the Prehistoric Society 66: 89-121. 